\title{
SISTEM PENDUKUNG KEPUTUSAN PENENTUAN KELAYAKAN LOKASI FRANCHISE PADA PT. SEMANGAT PAGI INDONESIA MENGGUNAKAN METODE SCORING SYSTEM
}

\author{
Welda $^{1)}$ Aniek Suryanti Kusuma ${ }^{2)}$ Sadam Mubaraq ${ }^{3)}$ \\ Program Studi Teknik Informatika1) 2) 3) \\ STMIK STIKOM Indonesia, Bali ${ }^{1)}{ }^{2}$ ) 3 ) \\ welda@stiki-indonesia.ac.id ${ }^{1)}$ anieksuryanti@stiki-indonesia.ac.id ${ }^{2}$ \\ sadam.mubaraq20@gmail.com ${ }^{3)}$
}

\begin{abstract}
PT. Semangat Pagi Indonesia is a company engaged in the field of services and sales. One example of the service offered is opening a gym. PT. Semangat Pagi Indonesia already has several fitness centers in some areas, especially on the island of Bali. In the vision and mission of the company, PT. Semangat Pagi Indonesia has annually achievements target to open 100 new branches in Indonesia by the year 2015 and by 2025 can open 1000 new branches in Southeast Asia. This research aims to build a decision support system to determine the feasibility of franchise location using Scoring System method, which will be used as a tool for the company in making a decision. Event List, Data Flow Diagram (DFD), and Entity Relationship Diagram (ERD) are used in designing this decision support system. The output of the system is in the form of eligibility information for each location submitted by the Franchisee. The type of eligibility given is a description whether the proposed location is feasible, very feasible, or less feasible. The testing of this system is using Black-Box method that will check the running of the system, whether the system is appropriate or not. Test results that have been done as expected. The end result from the system of this research, can help companies in taking a decision.
\end{abstract}

Keywords: decision support system, franchise, scoring system

\begin{abstract}
ABSTRAK
PT. Semangat Pagi Indonesia merupakan perusahaan yang bergerak di bidang jasa dan penjualan. Salah satu contoh pada bidang jasa adalah membuka tempat kebugaran. PT. Semangat Pagi Indonesia sudah memiliki beberapa tempat kebugaran di beberapa wilayah terutama di pulau bali. Dalam visi dan misi perusahaan, PT. Semangat Pagi Indonesia menargetkan dalam capaian perusahaan tahunan pada tahun 2015 dapat membuka 100 cabang baru di Indonesia dan pada tahun 2025 dapat membuka 1000 cabang baru Se-Asia Tenggara. Penelitian ini bertujuan untuk membangun sebuah sistem pendukung keputusan penentuan kelayakan lokasi franchise menggunakan Metode Scoring System, yang nantinya akan digunakan sebagai alat bantu perusahaan dalam mengambil sebuah keputusan. Hasil keluaran dari sistem adalah berupa informasi kelayakan bagi setiap lokasi yang diajukan oleh Franchises. Jenis kelayakan yang diberikan adalah keterangan apakah lokasi yang diajukan kurang layak, layak dan sangat layak. Pengujian sistem ini menggunakan metode Black-Box yang akan memeriksa jalannya sistem, apakah sistem telah sesuai atau tidak. Hasil pengujian yang telah dilakukan sesuai dengan yang diharapkan. Hasil akhir penelitian sistem ini, bisa membantu perusahaan dalam mengambil sebuah keputusan.
\end{abstract}

Kata Kunci: Sistem pendukung keputusan, Franchise, Scoring System 


\section{PENDAHULUAN}

Pada prinsipnya sistem pendukung keputusan membantu mengambil sebuah keputusan bukan menggantikannya. Rancang bangun sistem pendukung keputusan waralaba untuk mentukan lokasi yang ideal dibuat agar mempermudah para pemilik merek dagang dalam menentukan lokasi yang layak untuk membangun sebuah tempat usaha.

Menentukan posisi yang strategis untuk tempat kebugaran pada sistem bisnis waralaba bukan merupakan hal yang mudah. Dikarenakan bisnis ini punya sistem yang dijual dengan harga yang tidak murah. Jika seorang pembeli waralaba sudah mengeluarkan sejumlah biaya dan ternyata nilai penjualan tidak sesuai dengan harapan maka bisa jadi penempatan dari usaha tersebut kurang strategis. Beberapa pembeli sistem bisnis ini tak jarang pihak franchisee hanya bertahan dengan hitungan waktu yang sangat singkat. Hal ini diduga karena penempatan posisi tempat kebugaran tersebut yang kurang strategis.

PT. Semangat Pagi Indonesia merupakan perusahaan yang bergerak di bidang penjualan dan jasa. Salah satunya adalah bisnis waralaba pada Hawa Gym. Sering sekali seorang pembeli waralaba mengajukan kerjasama untuk bisnis ini. Namun calon franchisee tidak sedikit yang berhenti di tengah jalan. Dikarenakan mereka tidak memenuhi kriteria-kriteria yang diberikan oleh perusahan. Kadang pula hasil wawancara pada pembeli waralaba dengan di lapangan berbeda. Karena itu sistem pendukung keputusan perlu dimiliki agar menunjang kebutuhan data yang akurat oleh perusahaan guna mempermudah perusahan dalam mengambil keputusan. Pada sistem pendukung keputusan penentuan kelayakan lokasi franchise ini, perusahaan memberikan kriteria-kriteria persyaratan dimana setiap kriteria memiliki sub kriteria seperti di antaranya, kriteria gedung memiliki lima sub kriteria, kriteria tempat memiliki empat sub kriteria, kriteria teknis memiliki dua sub kriteria dan kriteria administrasi memiliki satu sub kriteria.

Setelah menentukan kriteria dan melihat hasil penentuan lokasi yang dimasukan oleh pihak franchisee, pihak perekrutan harus menentukan apakah pihak franchisee memenuhi kriteria untuk kemudian menerima dan memproseskannya menjadi sebuah keputusan. Pengambilan keputusan berdasarkan kriteria yang ada seringkali dihadapkan pada suatu permasalahan yang sulit ketika pihak perekrutan menemukan beberapa nilai yang bersifat subjektif dan dapat membingungkan pihak perekrutan dalam menentukan nilai keputusan. Dalam kondisi ini, bukan logika yang berperan dalam mengambil keputusan tetapi naluri pribadi pihak perekrutan. Demi memaksimalkan penilaian pihak perekrutan, banyak solusi yang ditawarkan, salah satu solusinya adalah dengan metode scoring system. Scoring system adalah salah satu metode yang memakai dua jenis data yaitu data kualitatif yang dinyatakan tidak dalam bentuk angka, namun berupa pernyataan, pendapat dan tanggapan. Dan juga data kuantitatif yang dinyatakan dalam bentuk angka dan bilangan-bilangan. Sehingga metode scoring system sangat cocok untuk digunakan dalam permasalahan ini. Terlebih lagi PT. Semangat Pagi Indonesia akan membuka cabang baru dalam target tahunan yaitu pada tahun 2015 menargetkan 100 cabang di Indonesia dan pada tahun 2025 menargetkan 1000 cabang se-Asia Tenggara.

Pada uraian diatas maka dibuatkan "Sistem Pendukung Keputusan menentukan kelayakan lokasi franchise pada PT. Semangat Pagi Indonesia menggunakan metode scoring berbasis website". Dengan dibangunnya sistem ini menggunakan website, diharapkan dapat membantu perusahaan dalam mengambil keputusan serta mempermudah pihak franchisee dalam registrasi tanpa harus datang langsung ke tempat lokasi perusahaan.

\section{TINJAUAN PUSTAKA}

\section{Sistem Informasi}

Jogiyanto (2005), mengemukakan bahwa sistem adalah kumpulan dari elemenelemen yang berinteraksi untuk mencapai suatu tujuan tertentu. sistem ini menggambarkan suatu kejadian-kejadian dan kesatuan yang nyata adalah suatu objek nyata, seperti tempat, benda, dan orang-orang yang betul-betul ada dan terjadi. Dengan demikian sistem merupakan kumpulan dari beberapa bagaian yang memiliki keterkaitan dan saling bekerja sama serta membentuk suatu kesatuan untuk mencapai suatu tujuan dari sistem tersebut. maksud dari suatu sistem adalah untuk mencapai suatu tujuan dan sasaran dalam ruang lingkup yang sempit.

\section{Sistem Pendukung Keputusan}

Menurut Turban (2005), penelitian tentang Sistem Pendukung Keputusan (SPK) merupakan suatu sistem interaktif yang membantu pengambilan keputusan melalui penggunaan data dan model-model keputusan 
untuk memecahkan masalah-masalah yang sifatnya semi terstruktur dan tidak terstruktur.

\section{Waralaba (Franchise)}

Menurut Munir (2005), menyatakan bahwa Franchise atau sering disebut juga dengan istilah waralaba adalah suatu cara melakukan kerjasama di bidang bisnis antara 2 (dua) atau lebih perusahaan, di mana 1 (satu) pihak akan bertindak sebagai franchisor dan pihak yang lain sebagai franchisee, di mana di dalamnya diatur bahwa pihak-pihak franchisor sebagai pemilik suatu merek dari know-how terkenal, memberikan hak kepada franchisee untuk melakukan kegiatan bisnis dari atas suatu produk barang atau jasa, berdasar dan sesuai rencana komersil yang telah dipersiapkan, diuji keberhasilannya dan diperbaharui dari waktu ke waktu, baik atas dasar hubungan yang eksklusif ataupun noneksklusif, dan sebaliknya suatu imbalan tertentu akan dibayarkan kepada franchisor sehubungan dengan hal tersebut.

\section{Lokasi Strategis}

Lokasi strategis menurut Lupiyoadi (2009), berhubungan dengan di mana perusahaan harus bermarkas dan melakukan operasi atau kegiatannya. Dalam hal ini ada tiga jenis interaksi yang mempengaruhi lokasi, yaitu:

1. Konsumen mendatangi pemberi jasa (perusahaan): apabila keadaannya seperti ini maka lokasi menjadi sangat penting. Perusahaan sebaiknya memilih tempat dekat dengan konsumen sehingga mudah dijangkau, dengan kata lain harus strategis.

2. Pemberi jasa mendatangi konsumen: dalam hal ini lokasi tidak terlalu penting, tetapi yang harus diperhatikan adalah penyampaian jasa harus tetap berkualitas.

3. Pemberi jasa dan konsumen tidak bertemu secara langsung: berarti penyedia jasa dan konsumen berinteraksi melalui sarana tertentu seperti telepon, komputer, atau surat. Dalam hal ini lokasi menjadi sangat tidak penting selama komunikasi antara kedua pihak terlaksana dengan baik.

\section{Scoring System}

Scoring system disebut juga sebagai skor skala, memerlukan suatu norma pembanding agar dapat di interpretasikan secara kualitatif. Pada dasarnya interpretasi skor skala selalu bersifat normative, artinya makna skor diacukan pada posisi relatif skor dalam suatu kelompok yang telah dibatasi terlebih dahulu.
Hal ini dapat dilakukan dengan bantuan statistic deskriptif dari distribusi data skor kelompok yang umumnya mencakup banyaknya subjek (n) dalam suatu kelompok, mean skor skala (M), deviasi standard skor skala (s) dan varians $\left(\mathrm{s}^{2}\right)$, skor minimum (Xmin) dan maksimum (Xmax), dan statistic statistik lain yang dirasa perlu. Deskripsi data ini memberikan gambaran penting mengenai keadaan distribusi skor skala pada kelompok subjek yang dikenai pengukuran dan berfungsi sebagai sumber informasi mengenai keadaan subjek pada aspek variable yang diteliti.

Sedangkan untuk menerapkan metode Scoring System ke dalam sistem, suatu skor yang ditentukan melalui prosedur penskalaan akan menghasilkan angka-angka pada level pengukuran interval dan interpretasikan hanya dapat dihasilkan kategori-kategori atau kelompok-kelompok skor pada level ordinal. Skor-skor mentah (row score) yang dihasilkan suatu skala merupakan penjumlahan dari skor item-item dalam skala itu.

Relativitas hasil pengukuran selalu membawa permasalahan mengenai cara-cara pengelompokan (kategorisasi) apabila diperlukan pemisahan subjek ke dalam kelompok diagnosis yang berbeda. Kategori ini didasari oleh suatu asumsi bahwa skor subjek dalam kelompoknya merupakan estimasi dalam skor subjek dalam populasi dan bahwa skor subjek dalam populasinya terdistribusi secara normal.

Kategori jenjang (ordinal) menurut Azwar (2003) kategori ini memiliki tujuan menempatkan individu ke dalam kelompokkelompok terpisah secara berjenjang menurut suatu kontinum berdasar atribut yang diukur. Kontinum jenjang ini contohnya adalah dari rendah ke tinggi, dari paling jelek ke paling baik, dari sangat tidak puas ke sangat puas, dan semacamnya. Banyaknya jenjang kategori diagnosis yang akan dibuat biasanya tidak lebih dari lima jenjang tetapi juga tidak kurang dari tiga jenjang. Misalnya mengelompokkan individu individu kedalam hanya dua jenjang diagnosis saja, yaitu "semangat kerja rendah" dan "semangat kerja tinggi" akan mengakibatkan resiko kesalahan yang cukup besar bagi skor-skor yang terletak disekitar mean kelompok.

Keterangan:

$\mathrm{X}=$ skor atau nilai

$\mu=$ mean teoritis

$\sigma=$ standar deviasi 
Langkah-langkah penentuan kategorisasi berdasarkan jenjang (ordinal) adalah sebagai berikut :

1. Menentukan data statistik secara deskriptif berupa rentang minimum (Xmin), rentang maksimum (Xmax), luas jenjang sebaran, mean teoritis $(\sigma)$ dan devisiasi standar $(\mu)$.

2. Menghitung data statistik secara deskriptif sebagai berikut : Xmin = banyaknya pertanyaan * nilai minimum

$\mathrm{Xmax}=$ banyaknya pertanyaan $*$ nilai maksimum

Luas jarak sebaran $=\mathrm{Xmax}-\mathrm{Xmin}$

$\sigma=$ luas jarak sebaran $/ 6$

$\mu=$ banyaknya pertanyaan $*$ banyak kategori

3. Menghitung $\mathrm{p}$ dengan menggunakan tabel distribusi normal, terlebih dahulu menentukan Zmin dan Zmax dengan rumus $: Z \min =(X \min -\mu) / \sigma$

$\mathrm{Zmax}=(\mathrm{Xmax}-\mu) / \sigma$

4. Memilih $\mathrm{p}$ dengan nilai yang maksimal sehingga dapat ditemukan rentang skala prioritas dengan 3 kategori, yaitu :

$\mathrm{X}<\left(\mu-\left(\mathrm{p}^{*} \sigma\right)\right)$ kategorinya rendah atau tidak layak

$(\mu-(\mathrm{p} * \sigma)) \leq X<(\mu+(\mathrm{p} * \sigma))$ kategotinya sedang atau layak $(\mu+(\mathrm{p} * \sigma)) \leq \mathrm{X}$ kategorinya tinggi atau sangat layak.

\section{Data Flow Diagram (DFD)}

Menurut Fatta (2008), Data Flow Diagram (DFD) merupakan diagram yang digunakan untuk menambahkan proses-proses yang terjadi pada sistem yang akan dikembangkan. Dengan model ini, data-data yang terlibat pada masing-masing proses dapat diidentifikasi. Pengembangan DFD biasanya menggunakan cara berjenjang. Dimulai dari Context Diagram, DFD level 0, DFD level 1, DFD level 2, dan seterusnya sesuai dengan kompleksitas dari sistem yang akan dikembangkan. Berikut adalah penjelasan dari Context Diagram, DFD, DFD level 0, level 1, dan DFD level 2 menurut Fatta (2008).

1. Context Diagram

DFD pertama dalam proses bisnis. Menunjukkan context dimana Proses bisnis berada. Menunjukkan semua proses bisnis dalam satu proses tunggal atau proses nol. Context diagram juga menunjukkan sebuah entitas luar yang menerima informasi dari atau memberikan informasi ke sistem.

2. Level 0 Diagram

Menunjukkan semua proses utama yang menyusun keseluruhan sistem. Level ini juga menunjukkan komponen internal dari proses dan menunjukkan bagaimana proses proses utama direalisasikan menggunakan data flow. Pada level ini juga ditunjukkan bagaimana proses-proses utama terhubung dengan entitas eksternal. Pada level ini juga dilakukan penambahan data store.

3. Level 1 Diagram

Umumnya diagram level 1 diciptakan dari setiap proses utama dari level 0 . Level ini menunjukkan proses proses internal yang menyusun setiap proses-proses utama dalam level 0 , sekaligus menunjukkan Bagaimana informasi berpindah dari satu proses ke proses yang lainnya. Jika misalnya proses induk dipecah, katakanlah menjadi tiga proses anak, maka tiga proses anak ini secara utuh menyusun proses induk.

4. Level 2 Diagram

Menunjukkan semua proses yang menyusun sebuah proses pada level 1. Bisa saja penyusunan DFD tidak mencapai level 2 ini. Atau mungkin harus dilanjutkan ke level berikutnya.

Menurut Fatta (2008), ada empat elemen yang menyusun suatu DFD yaitu sebagai berikut:

1. Proses

Aktivitas yang dilakukan untuk alasan bisnis yang spesifik, biasa berupa manual maupun terkomputerisasi.

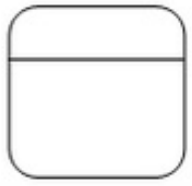

Gambar 1. Simbol Proses Menurut Gane dan Sarson

\section{Data Flow}

Satu data tunggal atau kumpulan logis suatu data, selalu diawali atau berakhir pada suatu proses.

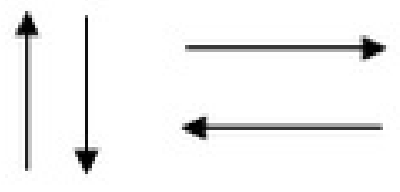

Gambar 2. Simbol Data Flow Menurut Gane dan Sarson

\section{Data Store}

Kumpulan data yang disimpan dengan cara tertentu. Data yang mengalir disimpan dalam data store. Aliran data di update atau ditambahkan ke data store. 


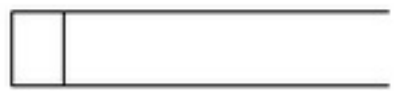

Gambar 3. Simbol Data Store Menurut Gane dan Sarson

\section{External Entity}

Orang organisasi atau sistem yang berada di luar sistem tetapi berinteraksi dengan sistem.

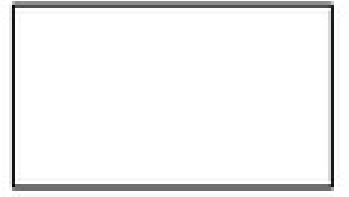

Gambar 4. Simbol External Entity Menurut Gane dan Sarson

\section{Entity Relationship Diagram (ERD)}

Menurut Ladjamuddin (2005), ERD (Entity Relationship Diagram) adalah diagram yang menunjukan informasi dibuat, disimpan, dan digunakan dalam sistem bisnis.

Simbol standar yang digunakan dalam membuat Entity Relationship Diagram diantaranya:

1. Entity / Entitas

Suatu kumpulan objek atau sesuatu yang dapat dibedakan atau dapat didefinisikan.

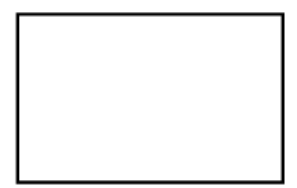

Gambar 5. Simbol Entity / Entitas

2. Relationship / Relasi

Hubungan yang dapat terjadi antara satu entitas atau lebih.

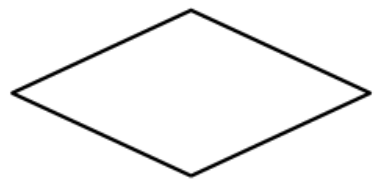

Gambar 6. Simbol Relationship / Relasi

3. Attribut / Atribut

Karakteristik entitas atau relationship yang menyediakan penjelasan detail entitas atau relationship.

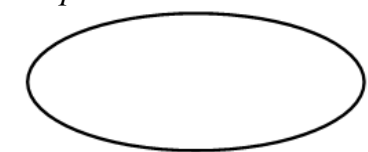

Gambar 7. Simbol Attribut / Atribut
Baris sebagai penghubung antara himpunan, relasi dan himpunan entitas dan atributnya.

Gambar 8. Simbol Line / Garis

\section{Wawancara}

Wawancara adalah proses memperoleh keterangan untuk tujuan penelitian dengan cara Tanya jawab sambil bertatap muka antara pewawancara dengan responden. Peneliti melakukan wawancara dengan Bapak Wawan selaku pihak marketing untuk mendapatkan data yang akurat tentang bisnis franchise. Pada kesimpulannya sistem yang masih konvensional perlu ditingkatkan menjadi sebuah sistem yang terkomputerisasi supaya dapat membantu perusahaan dalam mengambil sebuah keputusan yang dimana masih saat ini masih menggunakan penilaian berupa penalaran yang mengacu pada aspek penilaian pada hasil pengisian pada form franchise.

\section{Observasi}

Observasi adalah suatu teknik pengumpulan data dengan mengadakan pengamatan langsung ke PT. Semangat Indonesia di Denpasar. Penulis secara langsung mengamati proses-proses yang terjadi yaitu seluruh proses pencatatan data masih konvensional dengan pengisian data di form franchise kemudian form tersebut bisa dikirim langsung ke perusahaan atau melakukan pengisian data lewat via e-mail dan melakukan penilaian masih secara perkiraan.

\section{Dokumentasi}

Dalam penelitian ini dokumentasi berupa rekaman wawancara dan berupa berkas-berkas yang didapat langsung dari PT. Semangat Pagi Indonesia.

\section{Kepustakaan}

Merupakan pengumpulan data dengan mencari pustaka yang menunjang penelitian yang akan dikerjakan. Pustaka tersebut dapat berupa buku, jurnal, artikel, laporan tugas akhir, dan penelitian melakukan pencarian data-data yang berkaitan dengan metode scoring system.

4. Line / Garis 


\section{1) Analisis Sistem}

Seorang franchisee dapat memasukan biodata, data lokasi dan memasukan kriteria yang sudah disiapkan. Kemudian dari kriteriakriteria tersebut akan melakukan proses perhitungan scoring system dan setelah itu semua data tersebut akan tersimpan ke database. Sementara admin dapat melihat biodata franchisee, data lokasi,data kriteria dan melihat hasil penilaian yang dimasukan oleh pihak franchisee. Rancangan sistem tentang gambaran umum sistem pendukung keputusan pada bisnis franchise ini dapat dilihat pada gambar 9.

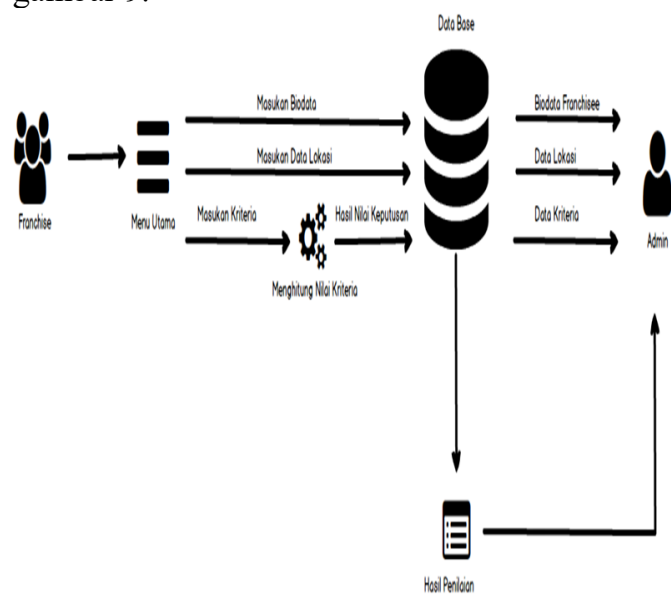

Gambar 9. Gambaran Umum Sistem

\section{2) Analisis Kasus Menggunakan Scoring System}

Sistem pendukung keputusan kelayakan lokasi franchise pada PT. Semangat Pagi Indonesia ini menggunakan metode Scoring System. Scoring System merupakan salah satu bentuk dari model pengambilan keputusan yang mampu menyajikan informasi dalam bentuk angka sehingga mudah untuk dipahami. Dengan digunakannya model ini, diharapkan mampu menyelsaikan permasalahan yang terjadi, yaitu menentukan nilai hasil keputusan franchise.

Terdapat beberapa tahapan untuk menentukan kelayakan lokasi berdasarkan kriteria-kriteria yang telah ditentukan. Untuk lebih jelasnya akan diambil sebuah contoh sebagai berikut:

$$
\begin{array}{ll}
\text { Nama } & \text { : Sadam Mubaraq } \\
\text { Email } & : \text { sadam.mubaraq20@gmail.com } \\
\text { No KTP } & : 5171042012940001 \\
\text { Lokasi } & \begin{array}{l}
\text { : jalan uluwatu 12 Kuta Selatan, } \\
\text { Badung, Bali }
\end{array}
\end{array}
$$

\begin{tabular}{|c|c|c|c|c|}
\hline Kriteria & Deskripsi & Jawab & Nilai & Skor \\
\hline \multirow[t]{4}{*}{$\begin{array}{l}\text { Kriteria } \\
\text { Tempat }\end{array}$} & $\begin{array}{l}\text { Jarak lokasi } \\
\text { usaha dari } \\
\text { kompetitor }\end{array}$ & $>5 \mathrm{KM}$ & 5 & \multirow{4}{*}{18} \\
\hline & $\begin{array}{l}\text { Perkiraan } \\
\text { jumlah rumah } \\
\text { di sekitaran } \\
\text { lokasi usaha }\end{array}$ & $\begin{array}{l}3000 \\
\text { Rumah } \\
-5000 \\
\text { Rumah }\end{array}$ & 4 & \\
\hline & $\begin{array}{l}\text { Lokasi } \\
\text { parkiran tidak } \\
\text { mengganggu } \\
\text { ketertiban lalu } \\
\text { lintas } \\
\end{array}$ & Baik & 4 & \\
\hline & $\begin{array}{l}\text { Luas parkiran } \\
\text { dilokasi usaha }\end{array}$ & $>60 \mathrm{M}^{2}$ & 5 & \\
\hline \multirow[t]{5}{*}{$\begin{array}{l}\text { Kriteria } \\
\text { Gedung }\end{array}$} & $\begin{array}{l}\text { Luas } \\
\text { bangunan } \\
\text { gedung }\end{array}$ & $\begin{array}{l}>250 \\
\mathrm{M}^{2}\end{array}$ & 5 & \multirow{5}{*}{24} \\
\hline & $\begin{array}{l}\text { kondisi } \\
\text { gedung tahan } \\
\text { terhadap } \\
\text { guncangan }\end{array}$ & Baik & 4 & \\
\hline & $\begin{array}{l}\text { Gedung wajib } \\
\text { memiliki } \\
\text { ruang ganti } \\
\text { atau toilet }\end{array}$ & $\begin{array}{l}>3 \\
\text { Toilet }\end{array}$ & 5 & \\
\hline & $\begin{array}{l}\text { fasilitas yang } \\
\text { dibangun } \\
\text { dapat } \\
\text { menjangkau } \\
\text { keperluan } \\
\text { konsumen } \\
\text { seperti } \\
\text { internet dan } \\
\text { telepon }\end{array}$ & $\begin{array}{l}\text { Sangat } \\
\text { baik }\end{array}$ & 5 & \\
\hline & $\begin{array}{l}\text { Kekuatan } \\
\text { daya listrik }\end{array}$ & $\begin{array}{l}>4000 \\
\text { KWH }\end{array}$ & 5 & \\
\hline \multirow[t]{2}{*}{$\begin{array}{l}\text { Kriteria } \\
\text { Teknis }\end{array}$} & $\begin{array}{l}\text { Penduduk di } \\
\text { sekitar lokasi } \\
\text { usaha tinggi } \\
\text { minat untuk } \\
\text { berolahraga }\end{array}$ & Baik & 4 & \multirow[t]{2}{*}{8} \\
\hline & $\begin{array}{l}\text { Potensi } \\
\text { perkembangan } \\
\text { usaha } \\
\text { kedepannya } \\
\text { dapat } \\
\text { menguntungk } \\
\text { an }\end{array}$ & Baik & 4 & \\
\hline $\begin{array}{l}\text { Kriteria } \\
\text { Admini } \\
\text { strasi }\end{array}$ & $\begin{array}{l}\text { Telah } \\
\text { mengurus } \\
\text { surat } \\
\text { perizinan } \\
\text { seperti SIUP, } \\
\text { TDP, NPWP } \\
\text { dan NPPKP } \\
\text { sebagai syarat } \\
\text { untuk } \\
\text { mendirikan } \\
\text { usaha }\end{array}$ & Cukup & 3 & 3 \\
\hline
\end{tabular}

Table 1. Perhitungan Sampel Lokasi 
Dari table 1 didapatkan total skor secara keseluruhan adalah 53, total untuk kriteria tempat adalah 18, kriteria gedung 24, kriteria teknis 8 dan kriteria administrasi 3. Dari nilai diatas makan akan dijadikan acuan untuk melakukan kategorisasi.

\section{Pembahasan :}

Perhitungan katagori berdasarkan kriteria keseluruhan,skor 53 :
a. Jumlah item 12,
b. Xmin = banyaknya pertanyaan * nilai minimum $12 * 1=12$
c. $\quad \mathrm{Xmax}=$ banyaknya pertanyaan $*$ nilai maksimum $12 * 5=60$
d. Luas jarak sebaran $=\mathrm{Xmax}-\mathrm{Xmin}$ $60-12=48$
e. $\sigma=$ luas jarak sebaran $/ 6$ $48 / 6=8$
f. $\mu=$ banyaknya pertanyaan * banyak kategori $12 * 3=36$
g. $\quad Z \min =(X \min -\mu) / \sigma$ $(12-36) / 8=-3$
h. $\mathrm{Zmax}=(\mathrm{Xmax}-\mu) / \sigma$ $(60-36) / 8=3$

i. Nilai $Z \min =-3$ maka nilai Pmin pada tabel distribusi adalah 0.00135

j. Nilai $Z \max =3$ maka nilai Pmax pada tabel distribusi adalah 0.99865

k. $\mathrm{X}<(\mu-(\mathrm{p} * \sigma))$ kategorinya rendah atau tidak layak $\mathrm{X}<(36-(0.99865 * 8))=$ $\mathrm{X}<28$

1. $(\mu-(\mathrm{p} * \sigma)) \leq \mathrm{X}<(\mu+(\mathrm{p} * \sigma))$ kategorinya sedang atau layak (36 $(0.99865 * 8)) \leq \mathrm{X}<(36+(0.99865 *$ $8))=28 \leq X<44$

m. $(\mu+(p * \sigma)) \leq X$ kategorinya tinggi atau sangat layak $(36+(0.99865 * 8)) \leq X=$ $44 \leq \mathrm{X}$

n. Maka dengan skor 53, dalam kriteria keseluruhan franchisee dikatagorikan skala sangat layak

Maka dengan skor keseluruhan 53 , kelayakan lokasi yang diajukan oleh Sadam Mubaraq dikatagorikan sangat layak.

\section{3) Event List}

Event list (EL) merupakan daftar narasi stimulasi (daftar kejadian) yang terjadi dalam lingkungan kejadian dalam lingkungan dan mempunyai hubungan respon yang diberikan oleh sistem EL juga digunakan sebagai acuan pembuatan Data Flow Diagram, oleh karena itu dibutuhkan untuk memberikan pengambaran singkat tentang daftar narasi yang berhubungan dengan sistem pendukung keputusan yang dibangun EL, pada sistem ini adalah sebagai berikut:

1. Proses Login Admin

2. Mengelola Data Master

2.1. Mengelola Data Item

2.1.1. Edit Data Item

2.1.2. Tambah Data Item

2.2. Mengelola Data Lokasi

2.2.1. Edit Data Lokasi

2.2.2. Tambah Data Lokasi

2.2.3. Cari Data Lokasi

2.3. Mengelola Biodata Franchise

2.3.1. Edit Biodata Franchise

2.3.2. Tambah Biodata Franchise

2.3.3. Cari Biodata Franchise

2.4. Mengelola Data Kriteria

3. Proses Perhitungan scoring system

4. Proses Hasil Penilaian

5. Laporan

\section{4) Perancangan Data Flow Diagram (DFD) \\ a. Diagram Konteks}

Diagram Konteks merupakan level yang paling awal dari suatu DFD. Dalam Diagram Konteks terlihat entity-entity yang berperan dalam program aplikasi ini, yaitu admin dan pihak franchisee.

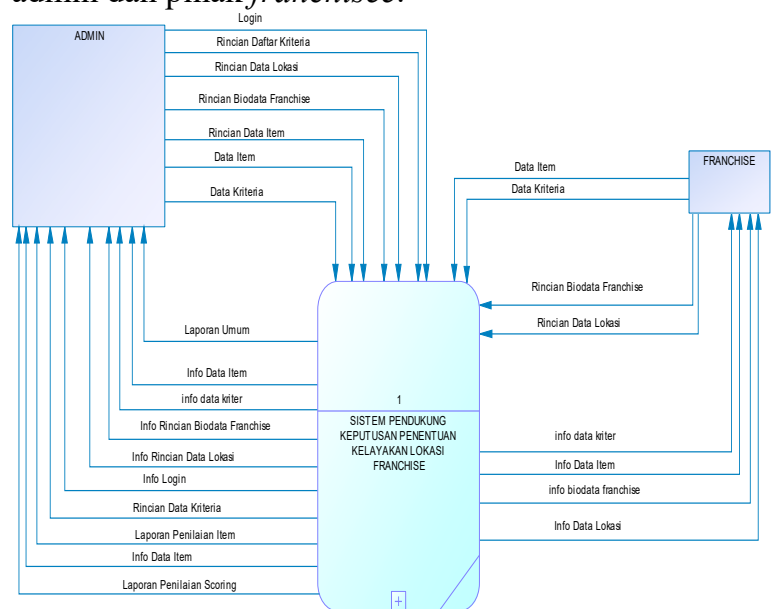

Gambar 10. Diagram Konteks

\section{b. Diagram Level 0 (Nol)}

Metode berarah aliran data dengan menggunakan DFD. Secara garis besar terdapat lima proses utama yaitu melakukan login, mengelola data master, proses perhitungan scoring system, proses rekap nilai kriteria dan laporan penilaian. Tahapan DFD dapat dilihat pada gambar 11 sebagai berikut: 


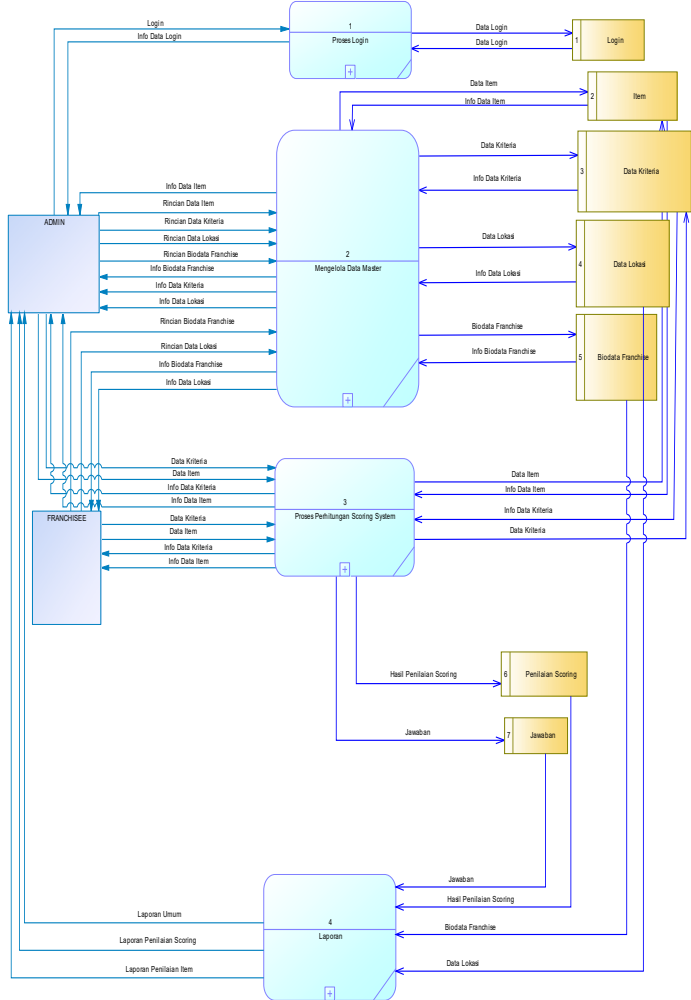

Gambar 11. Data Flow Diagram level 0

\section{c. Diagram level 1 Mengelola Data Master}

Pada gambar 12 mengelola data master, merupakan DFD level 1 yang menunjukan penjabaran dari sistem pendukung keputusan untuk mengelelola biodata franchisee, mengelola data lokasi, mengelola data item dan mengelola data kriteria. Berikut adalah DFD level 1 data master.

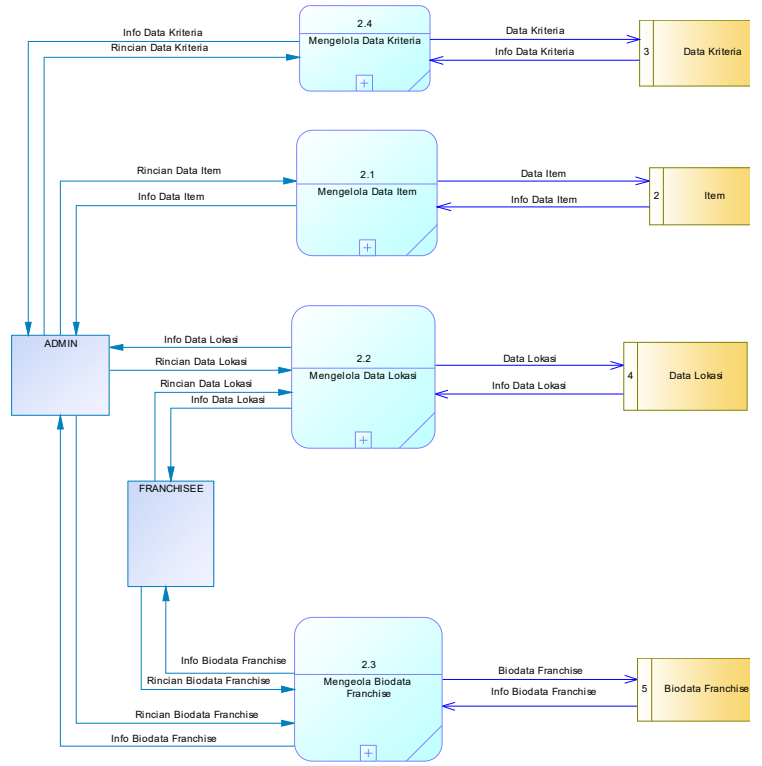

Gambar 12. Mengelola data master

\section{d. Diagram Level 2 Proses Mengelola Data Item \\ Pada gambar 13 di bawah ini} merupakan DFD level 2 proses mengelola data item pada level ini, mengelola aliran data item lebih terperinci dan diperjelas. Ada dua sub proses yang ada untuk proses data kriteria yaitu proses edit item dan proses tambah item. Berikut adalah DFD level 2 proses mengelola data kriteria.

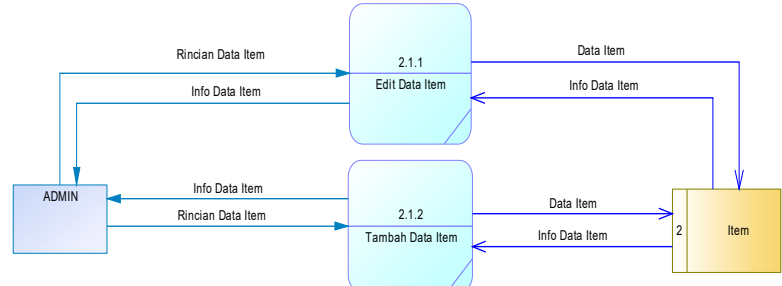

Gambar 13. DFD level 2 proses mengelola data item

\section{e. Diagram Level 2 Proses Mengelola Data Lokasi \\ Pada gambar 14 di bawah ini} merupakan DFD level 2 proses mengelola data lokasi. Pada level ini, mengelola aliran data lokasi lebih terperinci dan diperjelas. Ada tiga sub proses yang ada untuk proses data lokasi yaitu proses edit data lokasi, proses tambah data lokasi dan proses cari lokasi. Berikut adalah DFD level 2 proses mengelola data lokasi.

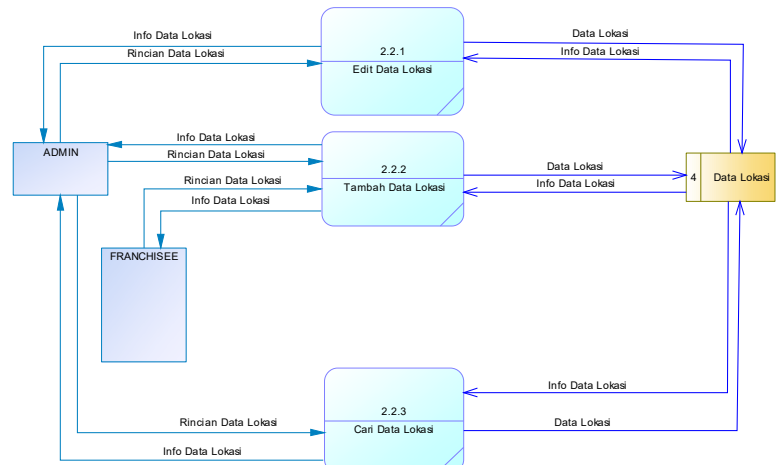

Gambar 14. DFD level 2 Proses mengelola data Lokasi

\section{f. Diagram Level 2 Proses Mengelola Biodata Franchise}

Pada gambar 15 di bawah ini merupakan DFD level 2 proses mengelola biodata franchisee. Pada level ini, mengelola aliran data lokasi lebih terperinci dan diperjelas. Ada tiga sub proses yang ada untuk proses biodata franchise yaitu proses edit biodata, proses tambah biodata dan proses cari biodata. Berikut DFD level 2 proses mengelola biodata franchise. 


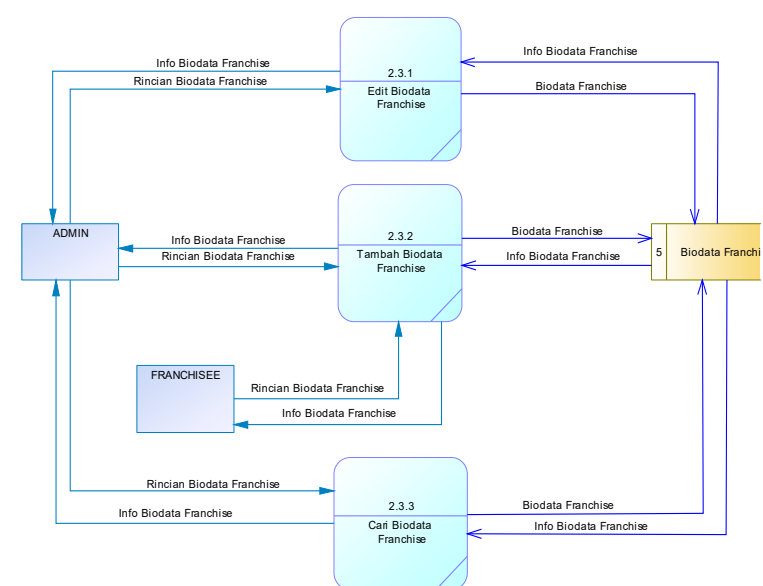

Gambar 15. DFD level 2 Mengelola Biodata Franchise

\section{5) ERD (Entity Relationship Diagram)}

Entity relationship diagram (ERD) adalah model konseptual yang mendiskripsikan hubungan antara penyimpanan (dalam DFD). ERD digunakan untuk memodelkan struktur data dan hubungan antar data. Pada rancang ERD sistem pendukung keputusan ini terdapat tujuh entitas yaitu: biodata franchise, data lokasi, data kriteria, detail penilaian kriteria gedung, detail penilaian kriteria tempat, detail penilaian kriteria keseluruhan dan laporan hasil penilaian.

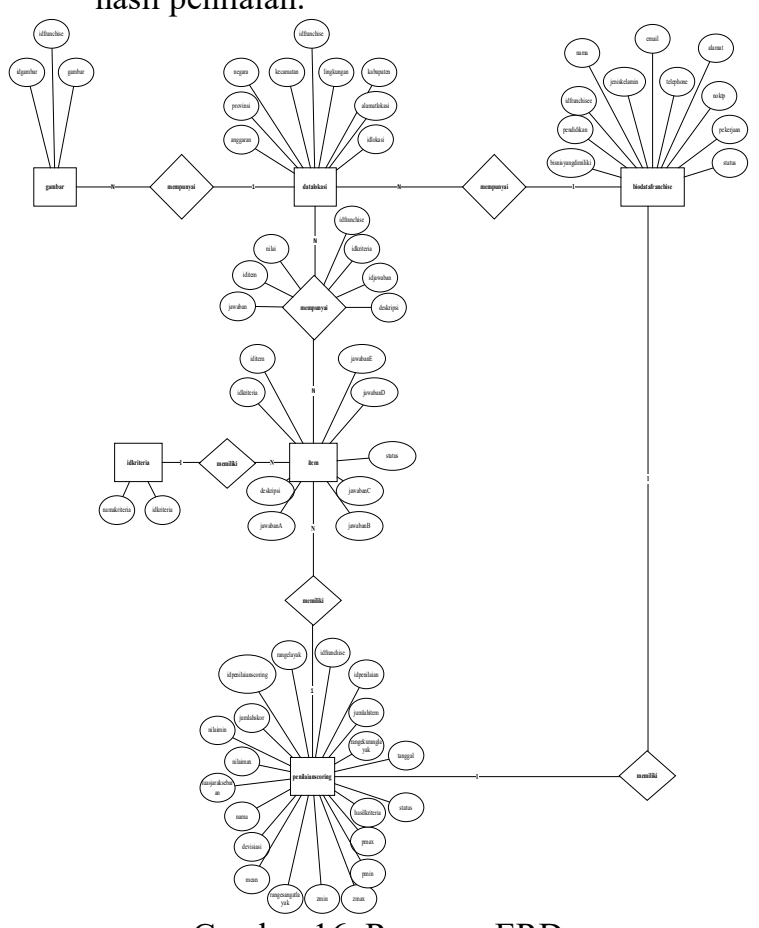

Gambar 16. Rancang ERD

\section{IMPLEMENTASI}

Implementasi sistem pada sistem pendukung keputusan ini akan dibatasi sesuai dengan ketentuan yang sudah dibahas sebelumnya, yaitu meliputi: tampilan data Franchisee, data lokasi, data list kriteria, menu admin dan yang lainnya.

\section{Halaman Menu Utama}

Tampilan pada halaman menu utama pada Gambar 17 terdapat dua buah tombol yaitu Login admin dan masuk sebagai franchisee. Tombol login admin berfungsi untuk proses login admin dan tombol franchisee berfungsi sebagai proses utama menuju halaman biodata franchisee. Berikut merupakan tampilan pada halaman menu utama.

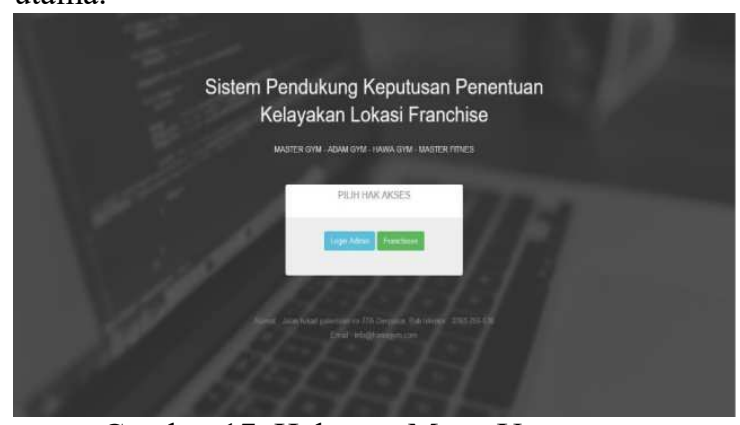

Gambar 17. Halaman Menu Utama

\section{Halaman Biodata Franchisee}

Tampilan pada halaman biodata franchisee pada Gambar 18 terdapat beberapa data yang harus di isi oleh pihak franchisee. Pada halaman biodata franchise juga terdapat tombol simpan untuk menyimpan data dan akan menuju halaman berikutnya serta tombol kembali untuk menuju halaman menu utama. Berikut merupakan tampilan pada halaman biodata franchisee.

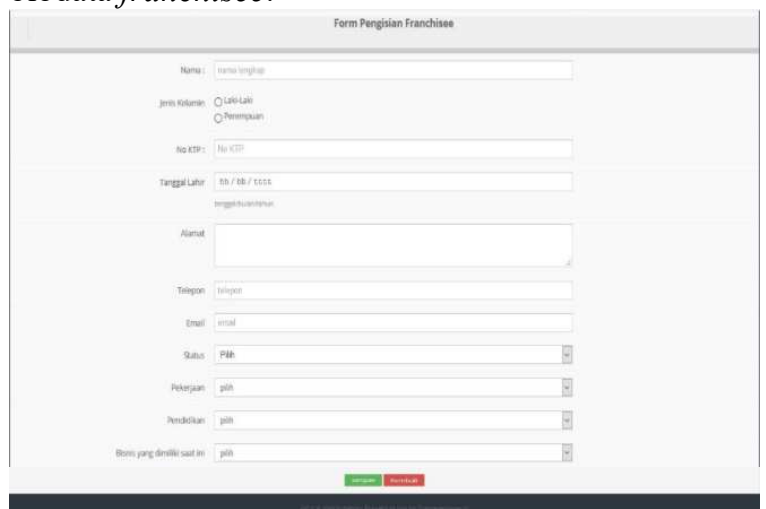

Gambar 18. Halaman Biodata Franchisee

\section{Halaman Data Lokasi}

Pada tampilan halaman data lokasi seperti Gambar 19 terdapat textbox data lokasi 
yang berisikan data lokasi yang harus dimasukan. Pada halaman data lokasi juga terdapat tombol telusuri untuk meng-upload foto, tombol simpan untuk menyimpan data dan akan menuju halaman berikutnya serta tombol ulangi untuk mengrefres data. Berikut merupakan tampilan pada halaman data lokasi.

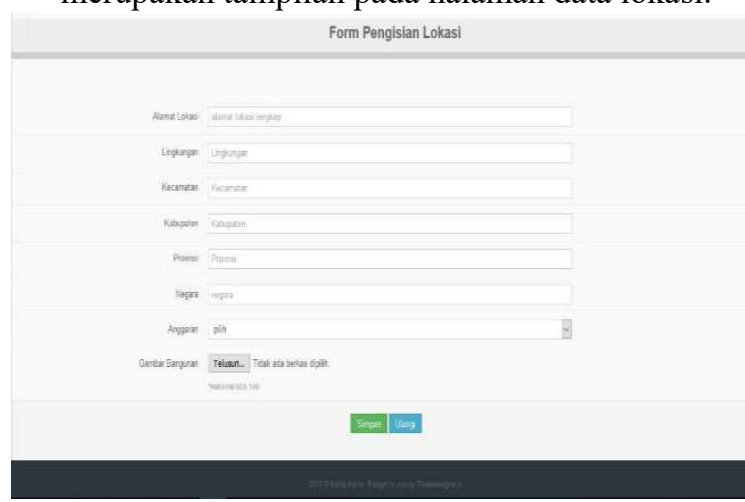

Gambar 19. Halaman Data Lokasi

\section{Halaman List Kriteria}

Pada tampilan halaman list kriteria seperti gambar 20 terdapat petunjuk cara menginputkan kriteria item. Dimasing-masing kriteria terdapat tombol isi jawaban untuk menginputkan kriteria item yang akan dimasukan oleh pihak franchisee dan tombol simpan untuk menyimpan data kriteria item yang telah dimasukan oleh pihak franchisee. Berikut merupakan tampilan halaman list kriteria.

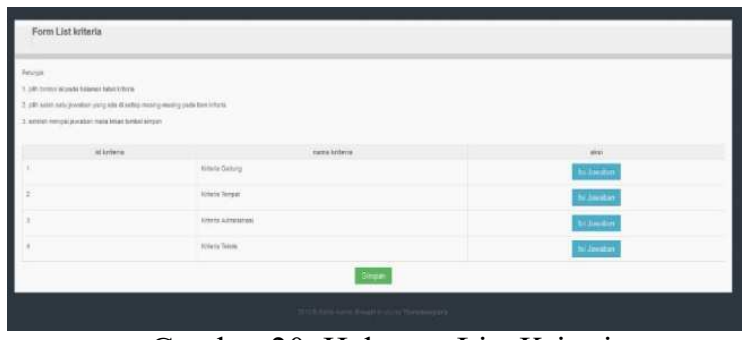

Gambar 20. Halaman List Kriteria

\section{Halaman Menu Utama Admin}

Pada tampilan halaman menu utama admin seperti gambar 22 terdapat beberapa menu diantara, tambah data, data franchisee, data lokasi, data kriteria, data penilaian dan laporan. Berikut merupakan tampilan halaman menu utama admin.

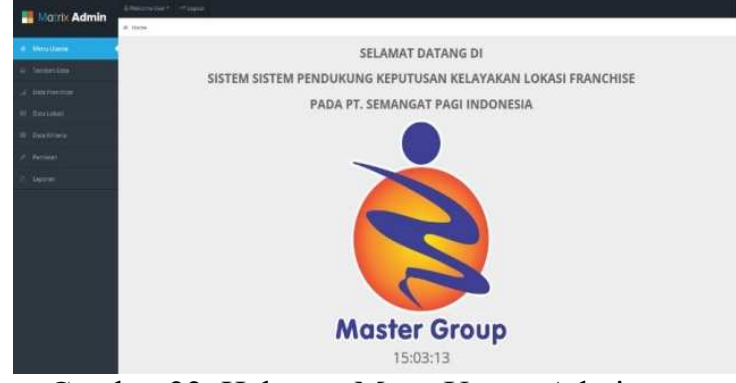

Gambar 22. Halaman Menu Utama Admin

\section{Halaman Tambah Data}

Pada tampilan halaman tambah data seperti gambar 23 terdapat beberapa rincian biodata franchisee dan tombol simpan untuk meyimpan biodata serta tombol kembali untuk kembali ke menu utama admin. Berikut merupakan tampilan halaman tambah data.

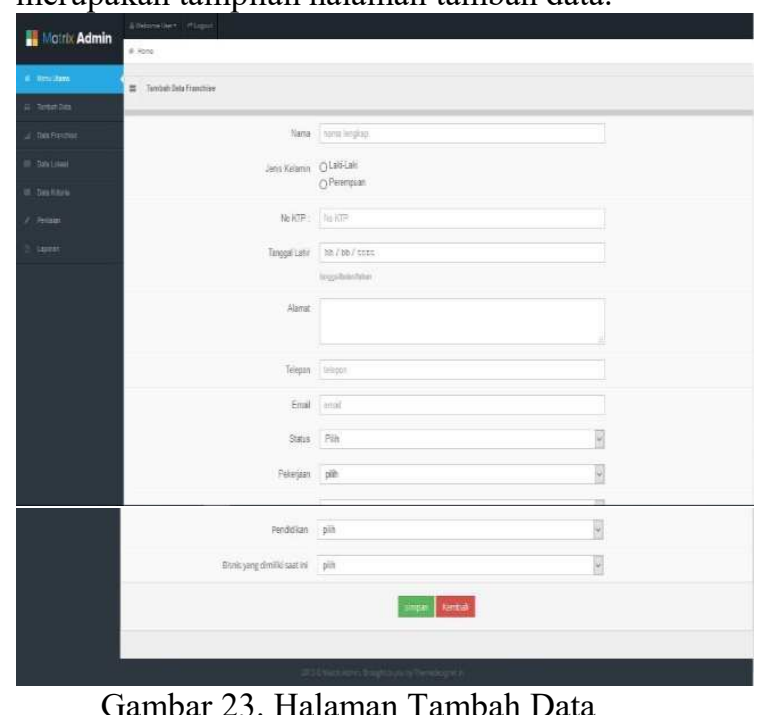

\section{Halaman Data Franchisee}

Pada tampilan halaman data franchisee seperti gambar 28 terdapat beberapa proses seperti proses melakukan pencarian berdasarkan nama franchisee dan proses ubah data franchisee. Berikut merupakan tampilan data franchisee.

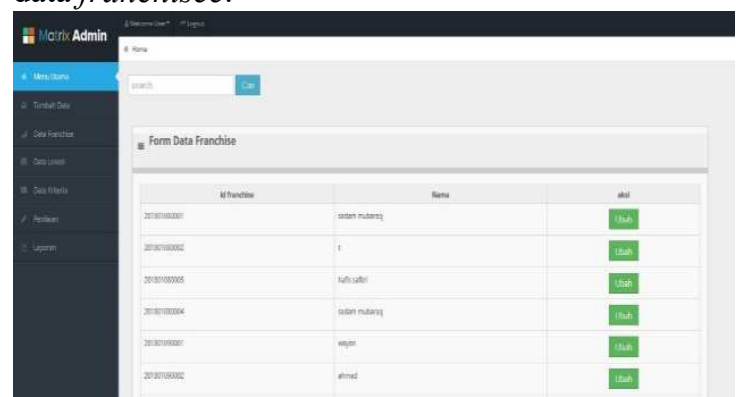

Gambar 28. Halaman Data Franchise 


\section{Halaman Data Lokasi}

Pada tampilan halaman data lokasi seperti gambar 29 terdapat beberapa proses seperti proses melakukan pencarian berdasarkan provinsi dan proses ubah data lokasi. Berikut merupakan tampilan data lokasi.

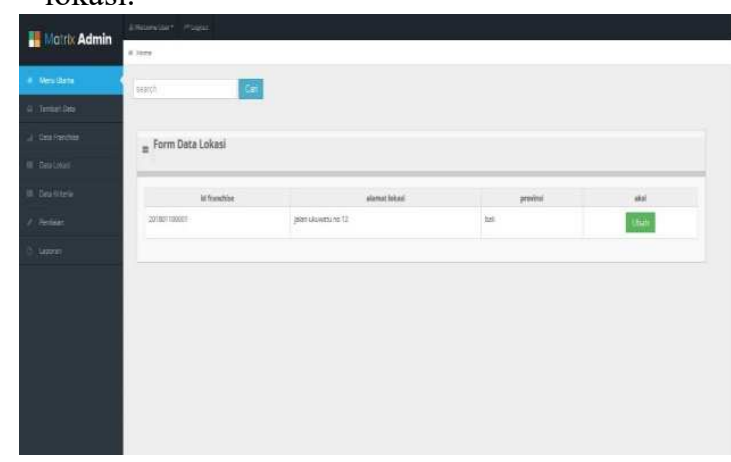

Gambar 29. Halaman Data Lokasi

\section{Halaman Data Kriteria}

Pada tampilan halaman kriteria seperti gambar 30 terdapat beberapa proses seperti menampilkan rincian kriteria pada tombol lihat, tombol tambah item untuk menambah kriteria item dan tombol ubah untuk ubah item yang terdapat pada tampilan kriteria item. Berikut merupakan tampilan halaman data kriteria.

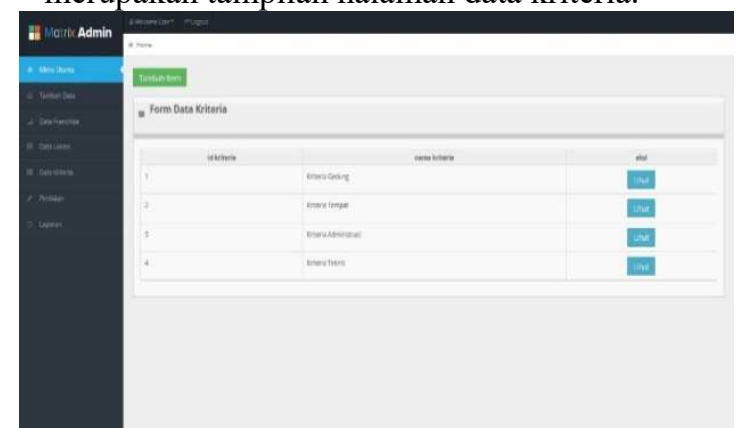

Gambar 30. Halaman Data Kriteria

\section{Halaman Penilaian Scoring System}

Pada tampilan halaman penilaian scoring system seperti gambar 31. terdapat tombol tampilkan untuk menampilkan penilaian scoring system. Berikut merupakan tampilan halaman penilaian scoring system.

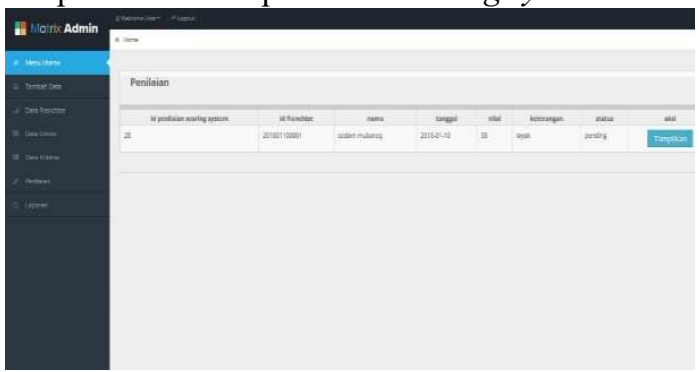

Gambar 31. Halaman Penilaian Scoring System

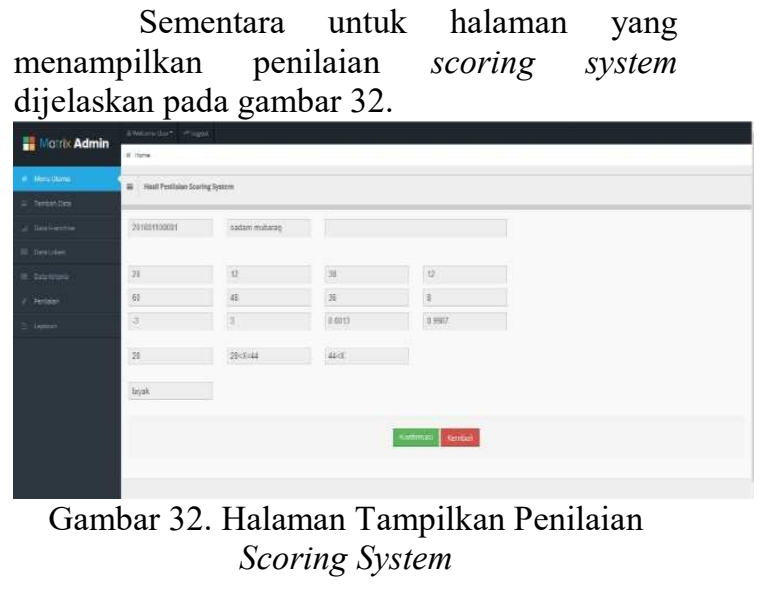

\section{Halaman Laporan}

Pada halaman laporan seperti gambar 33 terdapat beberapa proses seperti sub menu cetak laporan umum, laporan jawaban kriteria item dan laporan penilaian scoring system serta tombol cetak untuk mencetak laporan. Berikut merupakan tampilan halaman laporan umum.
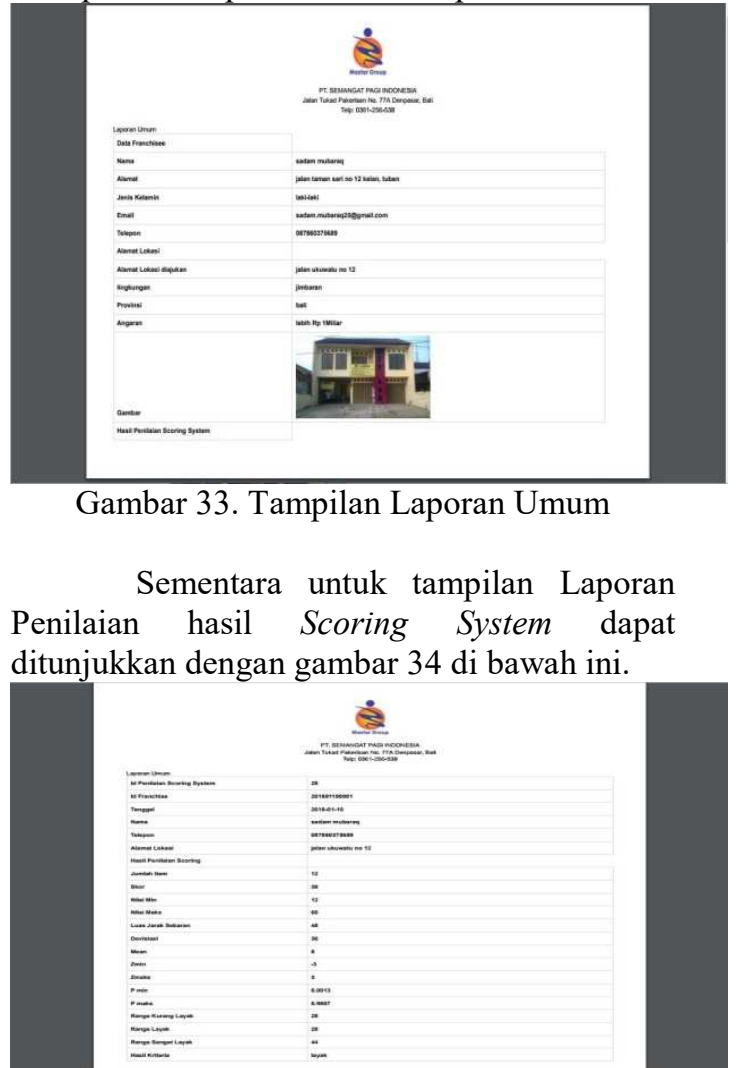

Gambar 34. Tampilan Laporan Penilaian Scoring System 


\section{SIMPULAN}

Berdasarkan kesimpulan yang diambil oleh penulis dalam perancangan sistem pendukung keputusan penentuan kelayakan lokasi franchise pada PT. Semangat Pagi Indonesia menggunakan metode scorimg system adalah sebagai berikut:

- Sistem pendukung keputusan penentuan kelayakan lokasi franchise memberikan rentang katagorisasi yang dapat digunakan sebagai standarisasi katagorisasi dengan jumlah katagori sebanyak 3 katagori yaitu kurang layak, layak dan sangat layak untuk penilaian keseluruhan.

- Hasil keputusan bisa dijadikan acuan untuk membantu perusahaan dalam mengambil keputusan.

- Hasil yang didapat lebih tepat dengan tingkat estimasi kesalahan minim.

\section{DAFTAR PUSTAKA}

[1] Azwar, Saifuddin. 2003. Reliabilitas dan Validitas. Yogyakarta: Pustaka Pelajar.

[2] Fatta, Hanif Al. 2008. Analisis dan Perancangan Sistem Informasi. Yogyakarta: ANDI Offset.

[3] Jogiyanto. 2005. Analisis dan Desain Sistem Informasi. Yogyakarta: Penerbit Andi.

[4] Lupiyoadi, Rambat dan A. Hamdani. 2009. Manajemen Pemasaran Jasa. Jakarta: Salemba Empat.

[5] Ladjamuddin, A.B. 2005. Analisis dan Desain Sistem Informasi. Yogyakarta: Graha Ilmu.

[6] Munir, Fuady. 2005. Perlindungan Pemegang Saham Minoritas. Bandung: CV. Utomo.

[7] Turban, Efraim, et al. 2005. Decision Support Systems and Intelligent Systems 7th Ed. New Jersey : Pearson Education. 